\title{
Effect of environmental salinity and dopamine injections on key digestive enzymes in hepatopancreas of the euryhaline crab Cyrtograpsus angulatus (Decapoda: Brachyura: Varunidae)
}

\author{
MARÍA SOLEDAD MICHIELS ${ }^{1,2}$, JUANA CRISTINA DEL VALLE ${ }^{1}$ \\ and ALEJANDRA ANTONIA LÓPEZ MAÑANES 1,2 \\ ${ }^{1}$ Departamento de Biología, Facultad de Ciencias Exactas y Naturales, Instituto de Investigaciones Marinas y Costeras \\ IIMyC-CONICET, Universidad Nacional de Mar del Plata, Argentina. \\ ${ }^{2}$ Consejo Nacional de Investigaciones Científicas y Tecnológias (CONICET), Argentina. E-mail: mananes@mdp.edu.ar
}

SUMMARY: We studied the occurrence and characteristics of lipase activity and the response of lipase and proteolytic activity to salinity and dopamine injections in hepatopancreas of the euryhaline crab (Cyrtograpsus angulatus). Lipase activity was maximal at $\mathrm{pH} 8.5$; it exhibited Michaelis-Menten kinetics (apparent $\mathrm{K}_{\mathrm{m}}=0.019 \mathrm{mM}$ ), was higher at $37^{\circ} \mathrm{C}$ and appeared to be cold tolerant, being also high at $4^{\circ} \mathrm{C}$. In $10 \mathrm{psu}$ (hyper-regulation conditions), lipase and proteolytic activity were about 3 and 5 times higher, respectively, than in 35 psu (osmoconformation). In 40 psu (hypo-regulation), lipase activity was about three times higher than in 35 psu, while proteolytic activity was similar. Lipase activity was inhibited in vivo by $10^{-4} \mathrm{M}$ dopamine in 35 psu but not in 10 or $40 \mathrm{psu}$. Proteolytic activity was not affected by $10^{-4} \mathrm{M}$ dopamine. The differential responses of lipase and proteolytic activity to salinity and dopamine suggest the occurrence of distinct digestive adjustments and mechanisms of regulation upon osmoregulatory conditions. This study contributes to a better understanding of the complexity of the biochemical adaptations to salinity in euryhaline crabs. The fact that higher digestive enzyme activities could be associated with a differential digestive capacity potentially leading to enhanced availability of energy substrates is discussed.

Keywords: Cyrtograpsus angulatus, euryhaline crabs, salinity, hepatopancreas, digestive enzymes, dopamine, Mar Chiquita lagoon.

RESUMEN: EFECTO DE LA SALINIDAD AMBIENTAL y DE LA INYECCión DE DOPAMINA SOBRE ENZIMAS Digestivas ClAVE EN hepatopáncreas del CANGRejo eurihalino Cyrtograpsus angulatus (Decapoda: Brachyura: Varunidae). - Se estudió la existencia y características bioquímicas de actividad de lipasa y la respuesta a salinidad y a dopamina de actividad de lipasa y proteolítica total en el hepatopáncreas del cangrejo eurihalino Cyrtograpsus angulatus. La actividad de lipasa fue máxima a $\mathrm{pH} 8,5$; mostró una cinética michaeliana $\left(\mathrm{K}_{\mathrm{m}}=0.019 \mathrm{mM}\right)$; fue mayor a $37^{\circ} \mathrm{C}$, y resistente a baja temperatura $\left(4^{\circ} \mathrm{C}\right)$. En $10 \mathrm{psu}$ (condición de hiperregulación), las actividades de lipasa y proteolítica fueron 3 y 5 veces mayores, respectivamente, que en 35 psu (condición de osmoconformación). En 40 psu (condición de hiporregulación), la actividad de lipasa fue de alrededor 3 veces mayor que en individuos aclimatados a 35 psu, mientras que la actividad proteolítica fue similar. La actividad de lipasa fue inhibida in vivo por dopamina $10^{-4} \mathrm{M}$ en 35 psu pero no fue afectada en 10 o 40 psu. Dopamina $10^{-4} \mathrm{M}$ no afectó la actividad proteolítica. Las respuestas de las actividades de lipasa y proteolítica a salinidad y a dopamina permiten sugerir la existencia de ajustes digestivos y mecanismos de regulación diferenciales en relación al estado osmorregulatorio. Los resultados constituyen un aporte relevante al conocimiento sobre las complejas adaptaciones a nivel bioquímico a la salinidad en cangrejos eurihalinos.

Palabras clave: Cyrtograpsus angulatus, cangrejos eurihalinos, salinidad, hepatopancreas, enzimas digestivas, dopamina, Laguna de Mar Chiquita. 


\section{INTRODUCTION}

Euryhaline crabs have to cope with frequent changes in environmental salinity and therefore require strategies at different levels for controlling movements of water and ions between the individuals and their medium (Anger 2001, Kirschner 2004). Hypo and hyper-osmoregulation involves the absorption or secretion of ions, respectively, to maintain hemolymph ion homeostasis (McNamara and Faria 2012, Romano and Zeng 2012). Hyper-osmoregulation requires the involvement of various branchial ion transport mechanisms such as $\mathrm{Na}^{+} / \mathrm{K}^{+}$-ATPase activity and carbonic anhydrase, although the extent, timing and activity in individual gills can be speciesspecific; hypo-osmoregulation responses appear more variable and may require different mechanisms (López Mañanes et al. 2000, 2002, Schleich et al. 2001, Bianchini et al. 2008, Freire et al. 2008, McNamara and Faria 2012, Romano and Zeng 2012). Biochemical adaptation to environmental salinity appears to be a complex process involving also the participation of enzymes and transport systems in extrabranchial tissues (Jahn et al. 2006, Pinoni and López Mañanes, 2004, 2008, 2009, Martins et al. 2011). The biochemical changes occurring in salinity adaptation require a metabolic reorganization to support increasing energy demands (Freire et al. 2008, McNamara and Faria 2012, Romano and Zeng 2012). Since digestive enzymes constitute a link between digestion and absorption, modulation of their activity in the hepatopancreas (the major site of digestive enzyme production) could lead to a greater availability of essential energy substrates (i.e. lipids and proteins) for salinity acclimation. The level of lipolytic and proteolytic activity in the hepatopancreas will determine the ability for digestion and/or utilization of lipids and proteins, respectively. The information on the occurrence and biochemical characteristics of digestive enzyme activities in the hepatopancreas is still scarce and fragmentary. We have recently shown the effect of low salinity acclimation on amylase activity in the hepatopancreas of Neohelice granulata in what is, to our knowledge, the first work on the subject in a euryhaline crab (Asaro et al. 2011). In field studies we showed that levels of lipase and proteolytic activity in the hepatopancreas of this crab differ between habitats in Mar Chiquita coastal lagoon (Buenos Aires, Province, Argentina), suggesting their participation in adaptive digestive and metabolic strategies to face the differential environmental conditions (i.e. salinity) (Pinoni et al. 2011). In the hepatopancreas of the euryhaline pacific white shrimp Litopenaeus vannamei, the responses of digestive enzymes activity to extreme environmental salinity has been suggested to be related to the possibility of deriving extra energy upon osmoregulation (Li et al. 2008).

Dopamine (DA) is an important neurotransmisor and neurohormone in crustaceans (Fingerman et al.
1994, Clark et al. 2008, Christie 2011) and has been shown to participate in the regulation of metabolic responses to environmental stresses (Lorenzon, 2005, Hsieh et al. 2006). In euryhaline crabs, DA is involved in the regulation of osmoregulation process by modulating osmolyte concentration in the hemolymph and branchial transport of $\mathrm{Na}^{+}$and $\mathrm{Na}^{+} /$ $\mathrm{K}^{+}$ATPase activity (Mo et al. 1998, Schleich et al. 1999, Morris 2001, Halperin et al. 2004, Genovese et al. 2006). Nothing is known about the effect of this biogenic amine on digestive enzyme activity in the hepatopancreas.

C. angulatus is a euryhaline crab that is found from Rio de Janeiro (Brazil) to Patagonia (Argentina) on the Atlantic coast and in Peru and Chile on the Pacific coast (Spivak 1997). Field studies indicate that $C$. angulatus behaves as omnivorous-detritivorous (Spivak 1997, Botto et al. 2005) but the digestive battery at the biochemical level (i.e. occurrence and level of lipase activity) underlying this feeding behavior has not been yet elucidated. In Mar Chiquita coastal lagoon, C. angulatus inhabits areas with abrupt, frequent, and highly variable changes in salinity ranging from 4 to 40 psu (and sometimes lower and higher values), indicating an extremely high degree of osmoregulatory capacity (Anger et al. 1994, Spivak et al. 1994, López Mañanes et al. 2002, Pinoni and López Mañanes 2004, 2008, Pinoni 2009). We have shown that biochemical acclimation to salinity of $C$. angulatus involves complex and integrative responses (López Mañanes et al. 2002, Pinoni and López Mañanes 2004, 2008, Pinoni 2009). The modulation of alkaline phosphatase activities in the hepatopancreas suggests the occurrence of digestive and metabolic adjustments in relation to salinity (Pinoni 2009, unpublished results). However, studies on the modulation of digestive enzymes are lacking. To increase knowledge of different aspects of the biology of $C$. angulatus and as part of our studies on the identification of enzyme activities involved in biochemical adaptation to salinity in hyper/hypo-regulating crabs, the aim of this work was to determine the occurrence and characteristics of lipase activity in the hepatopancreas and the response of lipase and total proteolytic activity to low and high salinity and dopamine injections.

\section{MATERIALS AND METHODS}

\section{Chemicals}

Azocasein, p-nitrophenylpalmitate, Tris-(hydroxymethylamino-methane) (Tris), ethyleneglicol $N, N^{\prime}, N^{\prime}$ tetraacetic acid (EGTA), bovine serum albumin and dopamine (3-hydroxytyramine) were from Sigma (St. Louis, MO, USA); sucrose and triclhoroacetic acid (TCA) were from Merck (Darmstadt, Germany); Coomasie blue G250 were from Fluka (Germany). All chemicals were of analytical grade. All solutions were prepared in glass-distilled water. 


\section{Animal collection and maintenance}

The crabs $(n=60)$ were caught from the mudflat area of Mar Chiquita coastal lagoon (Buenos Aires, Province Argentina) $\left(37^{\circ} 32^{\prime}-37^{\circ} 45^{\prime} \mathrm{S} ; 5^{\circ} 19^{\prime}-57^{\circ} 26^{\prime} \mathrm{W}\right)$. For all the experiments salinity was measured in practical salinity units (psu). Only adult male crabs with a carapace width greater than $2.5 \mathrm{~cm}$ were collected. Animals were transported to the laboratory in lagoon water on the day of collection. The crabs (20 individuals per aquarium) were maintained in natural seawater (35 psu), dilute sea-water (10 psu) or concentrated seawater (40 psu) for at least 10 days prior to use (Pinoni and López Mañanes 2004, 2008). Dilute seawater was obtained by dilution of natural seawater with distilled water. Concentrated seawater was obtained by addition of commercial marine salt (Red Sea Salt, Israel) to natural seawater (López Mañanes et al. 2000, Pinoni and López Mañanes 2004, 2008, Pinoni 2009). The aquaria contained $36 \mathrm{~L}$ of water, continuously aerated and filtered. A regime of $12 \mathrm{~h}$ light/12 $\mathrm{h}$ dark was applied and the temperature was kept at $22 \pm 2^{\circ} \mathrm{C}$. The water was continuously filtered by means of an Atman filter (HF-0400). Aquaria were shielded by black plastic to reduce disturbance. Crabs were fed three times a week with Vita fish commercial food (30\% carbohydrates, $44 \%$ protein, $12 \%$ fat; about $0.07 \mathrm{~g}$ individual ${ }^{-1}$ ) but they were starved $24 \mathrm{~h}$ prior to the experiments. No differences in the feeding behavior occurred in the experimental conditions used.

\section{Preparation of enzyme hepatopancreas extract}

The crabs were cryoanesthetized by putting them on ice for about $20 \mathrm{~min}$. The hepatopancreas was immediately excised, mixed with homogenizing medium (0.5 M Tris/ $\mathrm{HCl} \mathrm{pH} \mathrm{7.4;} 4 \mathrm{ml} \mathrm{g}^{-1}$ of hepatopancreas tissue) and homogenized (CAT homogenizer $\times 120$, tool T10) on ice. The homogenate was centrifuged at 10000 $\times \mathrm{g}$ for $15 \mathrm{~min}$ (Sorval, rotor SS34, refrigerated). The hepatopancreas from one individual was used for each preparation of enzyme extract. The supernatant was fractionated into $500 \mathrm{ul}$ aliquots and stored at $-20^{\circ} \mathrm{C}$ until use.

\section{Assay of enzyme activities}

In the standard assay, lipase activity was determined by measuring $p$-nitrophenylpalmitate (pNPP) hydrolysis (Markweg et al. 1995) with some modifications. The reaction was initiated by the addition of pNPP (final concentration $0.7 \mathrm{mM}$ ) to a reaction mixture containing a suitable aliquot of the corresponding sample (linearity zone on activity vs protein concentration plot) in $50 \mathrm{mM}$ Tris-HCl buffer $(\mathrm{pH} \mathrm{8.5)/4} \mu$ l of Tween 80 . Incubation was carried out at $37^{\circ} \mathrm{C}$ for $5 \mathrm{~min}$. The reaction was stopped by addition of $0.5 \mathrm{ml}$ of $0.2 \% \mathrm{w} / \mathrm{v}$ of TCA. The amount of released p-nitrophenol ( $\mathrm{pNP})$ was determined by reading the absorbance at $410 \mathrm{~nm}$
(Metrolab 330). To study the effect of $\mathrm{pH}$ and temperature on lipase activity, the procedure was the same as described above except that the activity was determined in the presence of varying $\mathrm{pH}$ (range 5.4-10.0) (50 mM phosphate buffer $\mathrm{pH}$ 5.4-6.4; $50 \mathrm{mM}$ Tris- $\mathrm{HCl}$ buffer $\mathrm{pH} 7.2-8.5 ; 50 \mathrm{mM}$ Glycine buffer $\mathrm{pH} 10.0)$ and temperature $\left(4-45^{\circ} \mathrm{C}\right)$ of the reaction mixture. To study the effect of pNPP concentration on lipase activity, the procedure was the same as described above except that the activity was determined in the presence of varying pNPP concentrations $(0.09-0.9 \mathrm{mM})$ in the reaction mixture. Individuals acclimated to $35 \mathrm{psu}$ were used in these experiments.

Total proteolytic activity was assayed by adding an aliquot of the corresponding sample (linearity zone on activity vs protein concentration plot) to a reaction mixture containing $1 \% \mathrm{w} / \mathrm{v}$ azocasein in $0.1 \mathrm{M}$ Tris$\mathrm{HCl}$ buffer $(\mathrm{pH} 7.5)$. The assay conditions used were optimal for this activity in the hepatopancreas of $C$. angulatus as described in previous work of our laboratory (Pinoni 2009). After incubation at $45^{\circ} \mathrm{C}$ for $30 \mathrm{~min}$, the reaction was arrested by adding $0.75 \mathrm{ml}$ of cold trichloroacetic acid (TCA) (10\% w/v) (Pinoni 2009, Pinoni et al. 2011). Overnight absorbance was measured at 440 $\mathrm{nm}\left(\mathrm{A}_{440}\right)$ (Metrolab 330) in the supernatant resulting after centrifuging at $1800 \times \mathrm{g}$ for $20 \mathrm{~min}$ (IEC-Centra $7 \mathrm{R}$, refrigerated). One unit activity (U) was defined as the amount of enzyme extract that produced an increase of 1 in $\mathrm{A}_{440}$. The proteolytic activity was expressed as $\mathrm{U} \mathrm{h}^{-1} \mathrm{mg}_{\text {protein }}{ }^{-1}$.

The determination of enzyme activity was always performed with samples that had been stored at $-20^{\circ} \mathrm{C}$, without any previous thawing.

Protein was assayed according to the method of Bradford (1976). Bovine serum albumin was used as standard. Absorbance was measured with a Metrolab 330 spectrophotometer.

\section{Hemolymph osmolality}

Hemolymph (about $500 \mu \mathrm{l}$ ) was sampled from the infrabranchial sinus of 5-10 individuals by means of a syringe at the base of the cheliped and transferred to an iced centrifuge tube. Serum was separated by centrifugation at $10000 \times \mathrm{g}($ Beckman, Microfuge, $\mathrm{B})$ for 30 s. Osmolality was measured with a micro-osmometer (Osmomat 030 D, GONOTEC).

\section{Effect of dopamine (DA) on digestive enzyme activity in hepatopancreas}

The effect of DA in vivo was determined as we described previously (Pinoni and López Mañanes 2004). After being cryoanesthetized for $20 \mathrm{~min}$, individuals $(n=5-10)$ were injected by means of a syringe at the base of the cheliped into the infrabranchial sinus with $100 \mu \mathrm{l}$ of saline solution $(400 \mathrm{mM} \mathrm{NaCl}, 10 \mathrm{mM} \mathrm{KCl})$ as control, or saline solution plus DA (final concentration $\left.10^{-4} \mathrm{M}\right)$. At $30 \mathrm{~min}$ after the injection, the corre- 

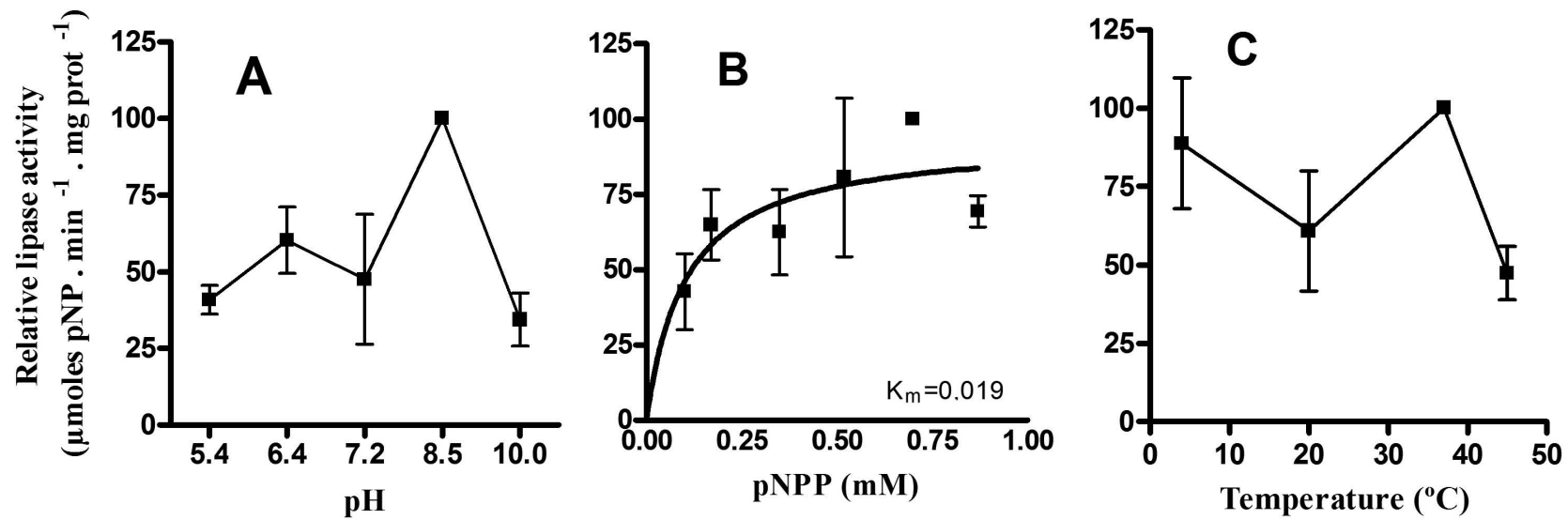

FIG. 1. - (A) Effect of $\mathrm{pH}$ (5.4-10.0) on lipase activity in hepatopancreas of $C$. angulatus. The activity was measured at $37^{\circ} \mathrm{C}$ and in the presence of $0.7 \mathrm{mM}$ p-nitrophenylpalmitate (pNPP). The lipase activity values are expressed as a relation to the specific activity at $\mathrm{pH} 8.5$ $\left(100 \%, 59 \pm 20 \mu\right.$ moles pNP min $^{-1} \mathrm{mg} \mathrm{prot}^{-1)}$. Data are the mean \pm SE for 5 individuals. (B) Effect of pNPP concentration on lipase activity in hepatopancreas of $C$. angulatus. The activity was measured at $37^{\circ} \mathrm{C}$ and at $\mathrm{pH} 8.5$. The activity values are expressed as a relation to the corresponding activity in the presence of $0.7 \mathrm{mM} \mathrm{pNPP}\left(100 \%, 50 \pm 18 \mu\right.$ moles pNP $\left.\mathrm{min}^{-1} \mathrm{mg} \mathrm{prot}^{-1}\right)$. Data are the mean \pm SE for 5 individuals (C) Effect of temperature $\left(4-45^{\circ} \mathrm{C}\right)$ on the lipase activity in hepatopancreas of individuals of C. angulatus. The activity was measured at $\mathrm{pH} 8.5$ and in the presence of $0.7 \mathrm{mM}$ pNPP. The activity is expressed in relation to the activity at $37^{\circ} \mathrm{C}\left(100 \%, 32 \pm 18 \mu \mathrm{mol} \mathrm{pNP} \mathrm{min}^{-1} \mathrm{mg} \mathrm{prot}^{-1}\right)$.

Data are mean $\pm \mathrm{SE}$ for 3 individuals.

sponding activity was determined in hepatopancreas as described above (standard assay conditions). For each individual (control and treated) the corresponding activities were assayed at least in triplicate. No mortality occurred during the experiment.

\section{Statistical analysis}

The results of the effect of different substrate concentrations on the enzymatic activities were analyzed by a nonlinear regression analysis (GraphPad Prism 4.0 software). The curve that appears is the one that best adjusts to the experimental data. The values of $\mathrm{K}_{\mathrm{m}}$ (constant of Michaelis-Menten) were estimated by the analysis of the data using the graph of LineweaverBurk (GraphPad Prism 4.0 software). The statistical analysis of the data was realised using the Sigma 3.0 program for Windows, which automatically performs a previous test of equality of variances and normality. A parametric analysis of variance was used (one-way ANOVA).

\section{RESULTS}

Lipase activity of hepatopancreas of Cyrtograpsus angulatus: effect of $\mathrm{pH}$, p-nitrophenylpalmitate (pNPP) and temperature

Lipase activity in the hepatopancreas was determined within the range of $\mathrm{pH}$ 5.4-10.0. Maximal activity was found at $\mathrm{pH} 8.5$. The activity was similar within the range 5.4-7.2 being about $40 \%-55 \%$ of the activity at $\mathrm{pH} 8.5$. At $\mathrm{pH} 10.0$ the activity decreased markedly, being about $35 \%$ of the activity at pH 8.5 (Fig. 1A). The effect of pNPP concentrations on lipase activity is shown in Figure 1B. Lipase activity in hepatopancreas of $C$. angulatus exhibited Michaelis-Menten kinetics

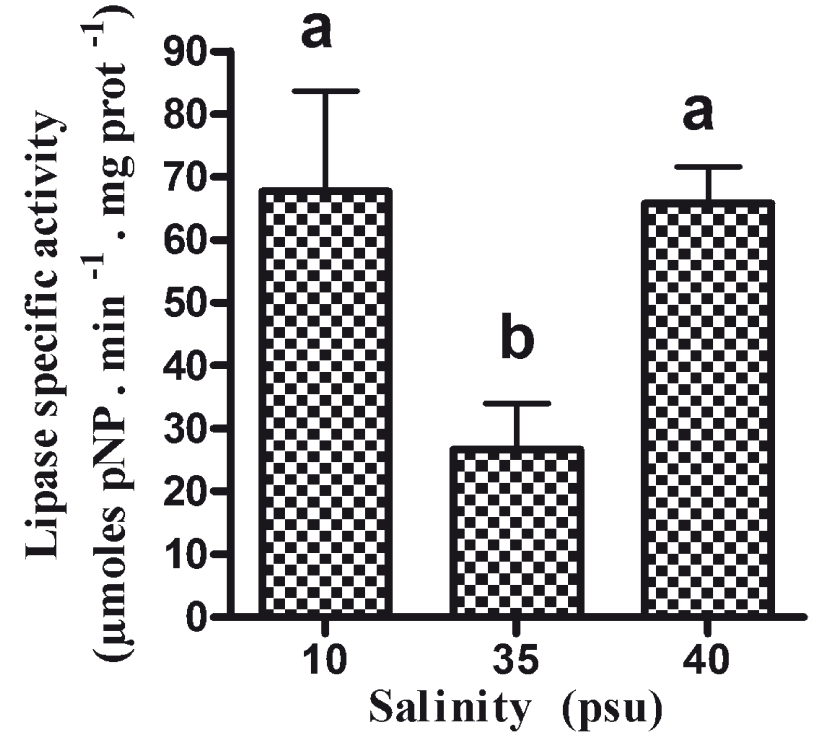

FIG 2. - Effect of acclimation to low and high salinity on lipase activity in hepatopancreas of $C$. angulatus. The activity was measured as described in the Materials and Methods section in the presence of $0.7 \mathrm{mM}$ p-nitrophenylpalmitate (pNPP) at $\mathrm{pH} 8.5$ and at $37^{\circ} \mathrm{C}$. Different letters indicate significant differences $(P<0.05)$. Data are mean \pm SE for 5 individuals.

(apparent $\mathrm{K}_{\mathrm{m}}=0.019 \mathrm{mM}$ ). Figure $1 \mathrm{C}$ shows the effect of temperature $\left(4-45^{\circ} \mathrm{C}\right)$ on lipase activity. The activity decreased between $4^{\circ} \mathrm{C}$ and $20^{\circ} \mathrm{C}$. At $37^{\circ} \mathrm{C}$ activity increased, reaching values similar to those at $4^{\circ} \mathrm{C}$ and at $45^{\circ} \mathrm{C}$ it decreased to about $47 \%$ of the activity at $37^{\circ} \mathrm{C}$.

\section{Effect of environmental salinity on digestive enzymes in hepatopancreas of Cyrtograpsus angulatus}

To determine the effect of environmental salinity on lipase and total proteolytic activity in hepatopan- 


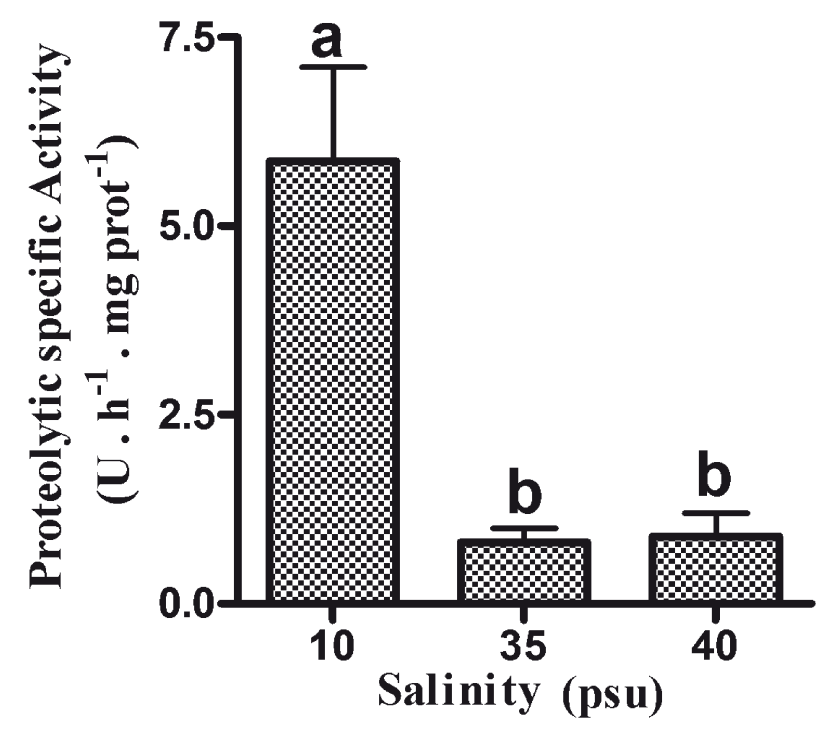

FIG 3. - Effect of acclimation to low and high salinity on proteolytic activity in hepatopancreas of $C$. angulatus. The activity was determined as described in the Materials and Methods section in the presence of $1 \% \mathrm{w} / \mathrm{v}$ azocasein at $\mathrm{pH} 7.5$ and $45^{\circ} \mathrm{C}$. Different letters indicate significant differences $(P<0.05)$. Data are mean \pm SE for 5 individuals.

creas, crabs were acclimated to 35,10 and 40 psu. The hemolymph osmolality of the crabs was significantly higher and lower from the external medium at 10 ( medium $=269 \pm 15$; hemolymph $=653 \pm 14$ ) and $40 \mathrm{psu}$ (medium $=1015 \pm 16$; hemolymph $=878 \pm 21$ ) respectively, while no differences were detected at 35 psu ( medium $=882 \pm 6$; hemolymph $=872 \pm 21$ ).

In individuals acclimated to low (10 psu) and high (40 psu) salinity, lipase activity was about three times higher than at $35 \mathrm{psu}\left(27 \mu\right.$ moles $\mathrm{pNP}$ min $\left.^{-1} \mathrm{mg} \mathrm{prot}^{-1}\right)$
(Fig. 2). Lipase activity of crabs acclimated to 10 and 40 psu was not significantly different from each other (Fig. 2).

Crabs acclimated to $10 \mathrm{psu}$ also exhibited a higher proteolytic activity in hepatopancreas (about five times) than crabs acclimated to 35 psu. On the other hand, crabs exposed to 40 psu exhibited a similar proteolytic activity to crabs acclimated to 35 psu (Fig. 3).

\section{Effect of dopamine injections on digestive enzymes in hepatopancreas of Cyrtograpsus angulatus}

DA $10^{-4} \mathrm{M}$ significantly decreased lipase activity (about 45\%) in hepatopancreas of crabs acclimated to 35 psu but had no effect on this activity in individuals exposed to 10 or 40 psu (Fig. 4A). DA $10^{-4} \mathrm{M}$ did not affect proteolytic activity in hepatopancreas at any salinity (Fig. 4B).

\section{DISCUSSION}

Our results show the occurrence of lipase activity in hepatopancreas of $C$. angulatus from Mar Chiquita coastal lagoon and the differential response of lipase and total proteolytic activity to low and high environmental salinity and dopamine. In crustaceans, the occurrence in the hepatopancreas of specific digestive enzyme activities has been related to the nature of the dietary components that could be potentially used for metabolic processes (Pavasovic et al. 2007, Figueiredo and Anderson 2009). The high lipase activity in hepatopancreas of $C$. angulatus is in accordance with the dietary habit of this crab in Mar Chiquita lagoon (Spivak 1997, Botto et al. 2005) and suggests the ability to perform lipid degradation and its potential use
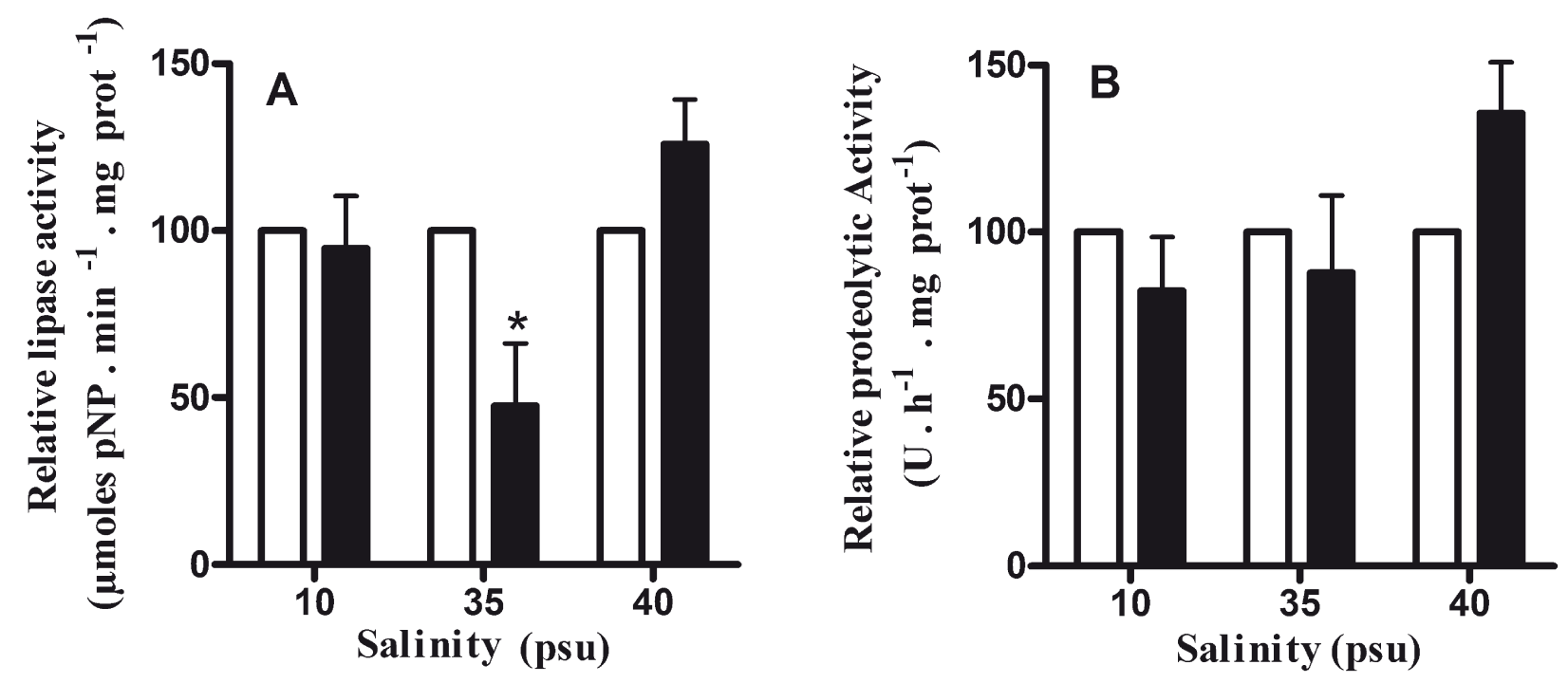

FIG 4. - Effect of DA on lipase activity and total protease activity in hepatopancreas of $C$. angulatus acclimated to different salinities. Lipase activity was measured as described in the Materials and Methods section in the presence of $0.7 \mathrm{mM}$ p-nitrophenylpalmitate (pNPP) at pH 8.5 and at $37^{\circ} \mathrm{C}$. Total protease activity was determined as described in the Materials and Methods section in the presence of $1 \%$ w/v azocasein at $\mathrm{pH} 7.5$ and $45^{\circ} \mathrm{C}$. Activity is expressed as a percentage (\%) of the activity of the corresponding control (without DA) (100\%). Data are mean \pm SE for 5-10 individuals. Open bars, control; black bars, DA $10^{-4} \mathrm{M}$. * Significantly different from the corresponding control $(P<0.05)$. 
as an energy source. The $\mathrm{pH}$ value for maximal lipase activity and the high level of activity throughout a wide range of $\mathrm{pH}$ (5.4-8.5) (Fig. 1A) is in agreement with that found for this enzyme in hepatopancreas of the euryhaline crab N. granulata (Michiels et al. 2011) and of the marine green crab Carcinus mediterranus (Cherif et al. 2007, Cherif and Gargouri 2009, Smichi et al. 2012). The high lipase activity at $37^{\circ} \mathrm{C}$ in hepatopancreas of C. angulatus (Fig. 1C) is also similar to that found in $N$. granulata (Michiels et al. 2011) but quite different from that described in C. mediterraneus (Cherif and Gargouri 2009, Smichi et al. 2012). Lipase activity in hepatopancreas of $C$. angulatus appeared to be strikingly high at low temperature $\left(4^{\circ} \mathrm{C}\right)$ (Fig. 1C). Since in Mar Chiquita coastal lagoon this crab is commonly exposed to low temperature (as low as $1^{\circ} \mathrm{C}$ ) (Spivak et al. 1994, personal observations), a cold tolerant lipase activity in the hepatopancreas could be related to a role in thermal acclimation (i.e. a higher digestion of lipids), as suggested for the copepod Calanus glacialis (Freese et al. 2012). However, this hypothesis requires further investigation. The Michaelis-Menten kinetics of lipase activity of hepatopancreas of $C$. angulatus (Fig. 1B) is in agreement with our preliminary results in hepatopancreas of $N$. granulata, to our knowledge, the only data on crabs (Michiels et al. 2011) and with those reported in the crayfish Procambrus clarki (Hammer et al. 2003) and the prawn Macrobrachium borellii (Pasquevich et al. 2011).

Osmoregulatory adaptation in response to salinity requires various molecular and biochemical changes such as increased gill $\mathrm{Na}^{+} / \mathrm{K}^{+}$-ATPase activity and/or hemolymph amino acids, which need energy (Freire et al. 2008, McNamara and Faria 2012, Romano and Zeng 2012). While this phenomenon has been studied extensively, some mechanisms are not fully understood, particularly from a metabolic perspective. In cultured crustaceans species, it has been suggested that dietary manipulation has the potential to improve the osmoregulatory abilities of individuals subjected to osmotically stressful conditions because osmoregulation requires energy that is sourced from lipids and or protein (Romano and Zeng 2012). Modulation of key digestive enzymes (i.e lipase and proteolytic activity) in the hepatopancreas could then lead to a greater availability of essential energy substrates (i.e lipids and protein metabolites) upon osmoregulation. $C$. angulatus behaves as a hyper/hypo-regulator because it exhibits hemolymph osmolality values higher and below lower than those of the corresponding external medium upon acclimation to $10 \mathrm{psu}$ and $40 \mathrm{psu}$, respectively, whereas it osmoconforms at 35 psu (López Mañanes et al. 2002, Pinoni and López Mañanes 2008, this study). These osmoregulatory responses reached after 10 days' acclimation are maintained stable for longer periods (up to three months) at all salinities tested (López Mañanes et al. 2002, Pinoni and López Mañanes 2008, Pinoni 2009, del Valle et al. 2012, unpublished results). We have shown that biochemical salinity adaptation in $C$. angulatus involves the differential and integrative modulation of $\mathrm{Na}^{+} / \mathrm{K}^{+}$-ATPase activity in individual anterior and posterior gills and $\mathrm{Na}^{+} / \mathrm{K}^{+}$-ATPase and alkaline phosphatase activity in chela muscle (López Mañanes et al. 2002, Pinoni and López Mañanes 2004, 2008, Pinoni 2009). The higher lipase activity in hepatopancreas of crabs acclimated to 10 psu and 40 psu (Fig. 2) suggests that modulation of this activity is another component of the biochemical adaptation to differential salinity. The enhanced lipase activity under salinity conditions implying hyper and hypo-regulatory responses (Fig. 2) could be related to a potential enhanced digestive capacity for lipids, leading in turn to a higher availability of energy metabolites upon osmoregulation. Since nothing is known about metabolic pathways and interrelation between organs and tissues in $C$. angulatus, a further experimental approach is required to test this hypothesis. In N. granulata, the changes in lipid metabolism (i.e mobilization from storage sites) must be related to the participation of these compounds as energy sources during salinity acclimation (Luvizotto-Santos et al. 2003, Pinoni and López Mañanes 2011). An adequate protein intake is essential to support the amino acid provision necessary to maintain key essential functions such as osmoregulation (Sánchez-Paz et al. 2006, Romano and Zeng 2012). Similarly to what we pointed out above concerning lipase activity, the higher proteolytic activity in the hepatopancreas of $C$. angulatus in low salinity (10 psu) than at 35 psu (osmoconformation) (Fig. 3) suggests a potential higher capability for the digestion of proteins upon hyper-regulation. Hyper and hypo-osmoregulation appear to require different mechanisms (McNamara and Faria 2012, Romano and Zeng 2012). The fact that lipase activity in hepatopancreas of $C$. angulatus was affected at both low and high salinity while proteolytic activity was only affected at low salinity (Figs 2 and 3 ) suggests the occurrence of differential digestive adjustments and consequently adjustments in the lipid and protein metabolism in relation to different osmoregulatory (hyper or hypo-regulation) responses. Parallel work in our laboratory shows that amylase activity in the hepatopancreas of $C$. angulatus would not be affected by salinity under the same conditions (unpublished results) and that a mobilization of glycogen from gills occurs only at high salinity (Asaro et al. 2012), further supporting the hypothesis of different specific metabolic adjustments for differential osmoregulatory responses. We have recently shown the different responses to low salinity of amylase and disaccharidase activity in the hepatopancreas of $N$. granulata (Asaro et al. 2011). In vitro experiments on muscle and hepatopancreas of $N$. granulata showed the occurrence of different adjustments in metabolic pathways (i.e. changes in the carbon amino acid flux between gluconeogenesis and lipid synthesis) in response to hypo and hyper-osmotic stress (Martins et al. 2011).

We have shown that injection of $10^{-4} \mathrm{M}$ DA increased hemolymph glucose levels and inhibited 
alkaline phosphatase activity in chela muscle of $C$. angulatus (López Mañanes 2004, Pinoni and López Mañanes 2004, del Valle et al. 2012). DA appears to be a key primary chemical messenger, having multiple effects and playing a role in regulatory pathways involved in the control of adaptive responses to salinity in this crab (López Mañanes 2004, Pinoni and López Mañanes 2004, del Valle et al. 2012). The mechanisms of regulation (i.e. primary chemical messengers) or factors involved in the modulation of the activity and/ or secretion of digestive enzymes in the hepatopancreas of crustaceans have been investigated little and are therefore very far from having been elucidated. The effect of DA on lipase activity in hepatopancreas of $C$. angulatus in vivo (Fig. 4) suggests that this biogenic amine is one primary chemical messenger involved in these mechanisms. Since the effect of DA on lipase activity occurred only in crabs acclimated to 35 psu, it can be speculated that the different response of this activity to salinity (Fig. 2) could be at least partially attributed to a differential activation of signaling pathways mediated by DA under osmoconforming and osmoregulating conditions. However, a role of other signaling pathways operating under osmoregulating conditions cannot be ruled out. Because the effect of DA on lipase activity was found in vivo, further studies are required to establish whether this effect involves its binding to specific receptors on hepatopancreas and/or on other target tissues inducing the secondary release of other messengers. The stimulation by DA of the release of glucose from hepatopancreas of $C$. angulatus in vitro, suggests its direct effect on this tissue (López Mañanes 2004). The effect of DA appeared to be specific on lipase activity since proteolytic activity was not affected at any salinity (Fig. 4). Work in our laboratory shows that maltase activity is also not affected (unpublished results). This suggests the occurrence of differential and specific mechanisms of modulation of the activity of digestive enzymes in the hepatopancreas of $C$. angulatus. In the American crayfish Orconectes limosus, in vitro experiments showed a differential release of digestive enzyme activity from the hepatopancreas stimulated by several vertebrate gastrointestinal hormones (Resch-Sedlmeir and Sedlmeir 1999). In the lobster Panulirus argus trypsin enzymes are regulated at the transcription and secretion level by distinct pandrial signals related to the quality of dietary proteins (Perera et al. 2012).

In conclusion, the results of this study show that lipase activity occurs in the hepatopancreas of $C$. angulatus and that lipase and proteolytic activity in the hepatopancreas are differentially affected upon acclimation to low and high salinity and DA injection, suggesting that they participate in the biochemical adaptation process to environmental salinity in this crab and that digestive enzymes have different modulation mechanisms. Whether these activities are involved in biochemical-physiological adjustments secondary to hyper-regulation and hypo-regulation (i.e. digestive adjustments leading to enhanced digestive capacity for lipids and proteins and for absorption of metabolites) remains to be investigated. Future studies will focus on establishing the exact physiological role of these responses in the hepatopancreas and other signaling pathways involved to provide a better understanding of the integrative responses and mechanisms of regulation underlying biochemical adaptation to salinity in C. angulatus in particular and in euryhaline crabs in general.

\section{ACKNOWLEDGEMENTS}

This study was partially supported by grants from the University of Mar del Plata and from the Consejo Nacional de Investigaciones Científicas y Tecnológicas (CONICET), Argentina

\section{REFERENCES}

Anger K. 2001. The Biology of Decapod Crustacean Larvae. Crustacean issues 14: 1-420.

Asaro A., del Valle J.C., López Mañanes A. 2011. Amylase, maltase and sucrase activities in hepatopancreas of the euryhaline crab Neohelice granulata (Decapoda: Brachyura: Varunidae): partial characterization and response to low environmental salinity. Sci. Mar. 75(3): 517-524.

Asaro A., del Valle J.C., López Mañanes A.A.2012. Responses to salinity in Cyrtograpsus angulatus: Osmoregulation and energy stores XIII Congress - XXXI Annual Meeting Rosario Society Biology. Biocell. 35(1): 67.

Bianchini A., Machado Lauer M., Nery L., Pinto Colares E., Monserrat J.M., dos Santos Filho E.A. 2008. Biochemical and physiological adaptations in the estuarine crab Neohelice granulata during salinity acclimation. Comp. Biochem. Physiol. A. 151: 423-436

Botto F., Valiela I., Iribarne O., Martinetto P, Alberti J. 2005. Impact of burrowing crabs on $\mathrm{C}$ and $\mathrm{N}$ sources, control and transformations in sediments and food webs of SW Atlantic estuaries. Mar. Ecol. Prog. Ser. 293: 155-164.

Bradford M.M. 1976. A rapid and sensitive method for the quantitation of microgram quantities of protein-dye binding. Anal. Biochem. 72: 248-254.

Cherif S., Fendri A., Miled N., Trabelsi H., Mejdoub H., Gargouri Y., 2007. Crab digestive lipase acting at high temperature: purification and biochemical characterization. Biochimie 89(8): 1012-1018.

Cherif S., Gargouri Y. 2009. Thermoactivity and effects of organic solvents on digestive lipase from hepatopancreas of the green crab. Food Chem. 116: 82-86

Clark M.C., Khan R., Baro D.J. 2008. Crustacean dopamine receptors: localization and $\mathrm{G}$ protein coupling in the stomatogastric ganglion. J. Neurochem. 104: 1006-1019

Christie A.E. 2011. Crustacean neuroendocrine systems and their signaling agents. Cell Tissue Res. 345: 41-67.

del Valle J.C., Panzeri A., López Mañanes A.A. 2012. Glucose homeostasis in the euryhaline crab Cyrtograpsus angulatus from Mar Chiquita coastal lagoon: regulation by dopamine XIII Congress - XXXI Annual Meeting Rosario Society Biology. Biocell. 35(1): 66.

Figueiredo M.S.R.B., Anderson A.J. 2009. Digestive enzyme spectra in crustacean decapods (Paleomonidae, Portunidae and Penaeidae) feeding in the natural habitat. Aquac. Res. 40(3): 282-291.

Fingerman M., Nagabhushanam R., Sarojini R., Palla Reddy, S. 1994. Biogenic Amines in Crustaceans: Identification, Localization, and Roles. J. Crustac. Biol. 14(3): 413-437

Freese D., Kreibich T., Niehoff B. 2012. Characteristics of digestive enzymes of calanoid copepod species from different latitudes in relation to temperature, $\mathrm{pH}$ and food. Comp Biochem Physiol . B. 162(4): 66-72.

Freire C.A., Onken H., McNamara J.C. 2008. A structure function analysis of ion transport in crustacean gills and excretory or- 
gans. Comp. Biochem. Physiol. A 151(3): 272-304.

Genovese G., Senek M., Ortiz N., Regueira M., Towle D.W., Tresguerres M., Luquet C.M. 2006. Dopaminergic regulation of ion transport in gills of the euryhaline semiterrestrial crab Chasmagnathus granulatus: interaction between D1- and D2like receptors. J. Exp. Biol. 209: 2785-2793.

Halperin J., Genovese G., Tresguerres M., Luquet C.M. 2004. Modulation of ion uptake across posterior gills of the crab Chasmagnathus granulatus by dopamine and cAMP. Comp. Biochem. Physiol. A 139: 103-109.

Hammer H.S., Bishop C.D, Watts S.A. 2003. The characterization of three digestive enzymes from the crayfish Procamabarus clarkii. J. Alabama Acad. Sci. 74(1): 47-59.

Hsieh S.L., Chen S.M., Yang Y.H., Ku C.M. 2006. Involvement of norepinephrine in the hyperglycemic responses of the freshwater giant prawn, Macrobrachium rosenbergii, under cold shock. Comp. Biochem. Physiol. A 143: 254-263.

Jahn M.P., Cavagni G.M., Kaiser D, Kucharski L.C. 2006. Osmotic effect of choline and glycine betaine on the gills and hepatopancreas of the Chasmagnathus granulata crab submitted to hyperosmotic stress J. Exp. Mar. Biol. Ecol. 334: 1-9.

Kirschner L B. 2004. The mechanism of sodium chloride uptake in hyperregulating aquatic animals. J. Exp. Biol. 207: 1439-1452.

Li E., Chen L., Zeng C., Yu N., Xiong Z., Chen X., Qin J.G. 2008. Comparison of digestive and antioxidant enzymes activities, haemolymph oxyhemocyanin contents and hepatopancreas histology of white shrimp, Litopenaeus vannamei, at various salinities. Aquaculture 274: 80-86.

López Mañanes A.A. 2004. Effect of dopamine on glucose levels in hemolymph of Cyrtograpsus angulatus. Abstracts XXIII Annual Meeting Rosario Biology Society. Biocell. 28(2): 225.

López Mañanes A.A., Magnoni L.J., Goldemberg A.L. 2000. Branchial carbonic anhydrase (CA) of gills of Chasmagnathus granulata (Crustacea Decapoda). Comp. Biochem. Physiol. B 127(1): 85-95.

López Mañanes A.A., Meligeni C.D., Goldemberg A.L. 2002. Response to environmental salinity $\mathrm{Na}^{+} / \mathrm{K}^{+}$-ATPase activity in individual gills of the euryhaline crab Cyrtograpsus angulatus. J. Exp. Mar. Biol. Ecol. 274: 75-85.

Lorenzon S. 2005. Hyperglycemic stress response in Crustacea. ISJ 2: $132-141$.

Luvizotto-Santos R., Lee J., Branco Z., Bianchini A., Nery L. 2003. Lipids as energy source during salinity acclimation in the euryhaline crab Chasmagnathus granulata (Crustacea-Grapsidae). J. Exp. Zool. A 295: 200-205.

Markweg H., Lang M.S., Wagner F. 1995. Decanoic acid inhibition of lipase from Acetinobacter sp. OPA 55. Enz. Microb. Tech. 17: $512-516$

Martins T.L., Chittó A.L.F., Rossetti C.R., Brondani C.K., Kucharski L.C., Da Silva R.S.M. 2011. Effects of hypo- or hyperosmotic stress on lipid synthesis and gluconeogenic activity in tissues of the crab Neohelice granulate. Comp. Biochem. Physiol. A 158(4): 400-405.

McNamara J.C., Faria S.C. 2012. Evolution of osmoregulatory patterns and gill ion transport mechanisms in the decapod Crustacea: a review. J. Comp. Physiol. B. doi: 10.1007/ s00360-012-0665-8.

Michiels M.S., Pinoni S.A., del Valle J.C., López Mañanes A.A. 2011. Lipase activity in hepatopancreas of the euryhaline crab Neohelice granulata: response in relation to osmoregulatory status Abstracts XXVII Annual Scientific Meeting Tucumán Biology Association, Tucumán, Argentina. Biocell. 35(2): 163.

Mo J.L., Devos P., Trausch G.1998. Dopamine as a modulator of ionic transport and $\mathrm{Na}^{+} / \mathrm{K}^{+}$-ATPase activity in the gills of the Chinese crab Eriocheir sinensis. J. Crustac. Biol. 18: 442-448.

Morris S. 2001. Neuroendocrine regulation of osmoregulation and the evolution of air-breathing in decapod crustaceans. J. Exp. Biol. 204: 979-989.

Pasquevich M.Y., Dreona M.S., Lavaría S., Heras H. 2011.Triacylglycerol catabolism in the prawn Macrobrachium borellii (Crustacea: Palaemoniade). Comp Biochem Physiol B. 160(4): $1-207$.

Pavasovic A., Anderson A.J., Mather P.B., Richardson N.A. 2007.
Influence of dietary protein on digestive enzyme activity, growth and tail muscle composition in redclaw crayfish, Cherax quadricarinatus. Aquac. Res. 38: 644-652.

Perera E., Rodríguez-Viera L., Rodríguez-Casariego J., Fraga I., Carrillo O., Martínez-Rodríguez G., Mancera J.M. 2012. Dietary protein quality differentially regulates trypsin enzymes at the secretion and transcription level in Panulirus argus by distinct signaling pathways. J Exp Biol. 215: 853-862

Pinoni S.A. 2009. Mecanismos de mantenimiento del medio interno en respuesta a estrés ambiental en crustáceos decápodos de interés regional. $\mathrm{PhD}$ thesis, Universidad Nacional de Mar del Plata. Mar del Plata.

Pinoni S.A., López Mañanes A.A. 2004. Alkaline Phosphatase activities with differential response to environmental salinity in muscle of Chasmagnathus granulata and Cyrtograpsus angulatus from Mar Chiquita coastal lagoon. Biocell. 28: 225.

Pinoni S.A., López Mañanes A.A. 2008. Partial characterization and response under hyperregulating conditions of $\mathrm{Na}^{+} / \mathrm{K}^{+}$-ATPase and levamisole-sensitive alkaline phosphatase activities in chela muscle of the euryhaline crab Cyrtograpsus angulatus. Sci. Mar. 72(1): 15-24

Pinoni S.A., López Mañanes A.A. 2009. $\mathrm{Na}^{+}$ATPase activities in chela muscle of the euryhaline crab Neohelice granulata: Differential response to environmental salinity. J. Exp. Mar. Biol. Ecol. 372(1-2): 91-97.

Pinoni S.A., Iribarne O., López Mañanes A.A. 2011.Between-habitat comparison of digestive enzymes activities and energy reserves in the SW Atlantic euryhaline burrowing crab Neohelice granulata. Comp. Biochem. Physiol. A 158: 552-559.

Pinoni S.A., López Mañanes A.A. 2011. Biochemical and physiological flexibility in

the euryhaline semiterrestrial crab Neohelice granulata from contrasting habitats. Abstracts XXVII Annual Scientific Meeting Tucumán Biology Association, Tucumán, Argentina Biocell. 134: $13-15$

Resch-Sedlmeier G., Sedlmeier D. 1999. Release of digestive enzymes from the crustacean hepatopancreas: effect of vertebrate gastrointestinal hormones. Comp. Biochem. Physiol. B 1(2): 187-192.

Romano N., Zeng C. 2012. Osmoregulation in decapod crustaceans: implications to aquaculture productivity, methods for potential improvement and interactions with elevated ammonia exposure. Aquaculture 334-337: 12-23.

Sánchez-Paz A., García-Carreño F., Muhlia-Almazan A., Peregrino-Uriarte A., Yepiz-Plascencia J.Y.G. 2006. Usage of energy reserves in crustaceans during starvation: status and future directions. Insect. Biochem. Mol. Biol. 36: 241-249.

Schleich C.E., López Mañanes A.A., Goldemberg A.L. 1999. Regulación por mensajeros químicos de la actividad $\mathrm{Na}^{+}-\mathrm{K}^{+}$ATPasa branquial de Chasmagnathus granulata (Crustacea Decápoda) de la laguna costera de Mar Chiquita (Pcia. de Buenos Aires) en condiciones de salinidad reducida. In: Trisierra, A.E., Aguilar, Z.G. (eds), COLACMAR, vol. 1. Culquichicón Malpica, Perú, pp. $529-530$.

Schleich C.E., Goldemberg A.L., López Mañanes A.A. 2001. Salinity dependent $\mathrm{Na}^{+} / \mathrm{K}^{+}$-ATPase activity in gills of euryhaline crab Chasmagnathus granulatus. Gen. Physiol. Biophys. 20: 255-256.

Smichi N., Fendri A., Zarai Z., Bouchaala E., Chérif S., Gargouri Y., Miled N. 2012. Lipolytic activity levels and colipase presence in digestive glands of some marine animals. Fish Physiol. Biochem. doi: 10.1007/s10695-012-9633-1 In press.

Spivak E. 1997. Cangrejos estuariales del Atlántico sudoccidental $\left(25^{\circ}-41^{\circ} \mathrm{S}\right)$ (Crustacea: Decapoda: Brachyura). Invest. Mar. Valparaíso. 25: 105-120.

Spivak E., Anger K., Luppi T., Bas C., Ismael D. 1994. Distribution and habitat preferences of two grapsid crab species in Mar Chiquita lagoon (Pcia. Bs As. Argentina). Helgolander Meeresun. 48: 59-78.

Scient. ed.: C. Zeng.

Received June 18, 2012. Accepted September 17, 2012.

Published online November 9,2012. 